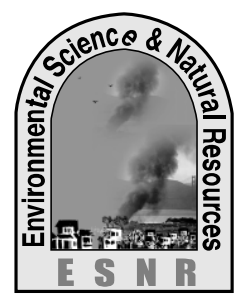

J. Environ. Sci. \& Natural Resources, 6(2): 207 - 212,2013

ISSN 1999-7361

\title{
Environmental Impact of Coal Mining: A case study on Barapukuria Coal Mining Industry, Dinajpur, Bangladesh
}

\author{
M. R. Hasan, H. Rashid and A. K. Paul
}

Department of Environmental Science and Resource Management, Mawlana Bhashani Science and Technology University

\begin{abstract}
The study revealed that the concentration of organic Carbon, $\mathrm{K}, \mathrm{Ca}, \mathrm{Mg}, \mathrm{P}, \mathrm{S}$ were $111.39 \mathrm{ppm}, 555.31 \mathrm{ppm}$, 200.73ppm, $11.10 \mathrm{ppm}, 220.20 \mathrm{ppm}, 1.48 \mathrm{ppm}$ respectively for coal water treated farm soil and $105.37 \mathrm{ppm}, 145.09 \mathrm{ppm}, 197.06$ ppm, $6.16 \mathrm{ppm}, 30.78 \mathrm{ppm}$, respectively for normal farmer's field soil and BOD, DO, temperature in mine drainage water were $2.14 \mathrm{ppm}, 2.44 \mathrm{ppm}, 6.6{ }^{\circ} \mathrm{C}$ respectively. Thus the effect of coal water, discharged from Barapukuria coal mine area to the surrounding agricultural fields was found good for organic carbon, $\mathrm{P}, \mathrm{S}, \mathrm{Ca}, \mathrm{Mg}$ fertility of soil but the continuous deposition of trace metals in the agricultural field soil may cause a serious deterioration of soil resources.
\end{abstract}

Key words: Coal Mining, Environmental impact, Mining industry

\section{Introduction}

Regionally, the Barapukuria coal basin is located in Dinajpur district of Bangladesh (Armstrong, 1991).The over increasing gap between supply and use of energy is a problem for many countries where governments are looking at increasing energy efficiency by using traditional fossil fuels. Due to abundant supply and the cheapest ways to create electricity from coal, developing countries are using this traditional option to create electricity (Jaccard, 2005). Because of deforestation, supply of traditional fuels is decreasing and becoming expensive day by day. Significant portion of export earning is being used to import of petroleum products and coal (Hamilton 2005). Coal is a very important but dirty fossil fuel. Coal mining has severe environmental, ecological, and human-health consequences. If not done properly, coal mining has potential to damage landscape, soils, surface water, groundwater, air during all phases of exploration and the resurgence coal as an energy source may come as a shock to some because of environmental impacts it has had in the past (Martha, 2001).Therefore this study was conducted at BCMI with the following objectives: a) to know the chemical properties of the of the coal, coal water and nearby agriculture field soil and b) to know that whether these chemical parameters polluting the environment of that area or not.

\section{Materials and methods}

\section{Study Area}

The study area is located within the Parbatipur Upazilla at approximately between the latitudes of $25^{\circ} 65^{\prime}$ and $25^{\circ} 33^{\prime} \mathrm{N}$ and between the longitudes of $88^{\circ} 55^{\prime}$ and $88^{\circ} 95^{\prime}$ at Dinajpur District (Banglapedia 2006). The Barapukuria basin is a long, narrow, and shallow Permo Carboniferous rift basin. trends approximately N-S for over $5 \mathrm{~km}$, ranges from 2 to $3 \mathrm{~km}$ wide, and is over The basin is $550 \mathrm{~m}$ deep. The overall structure of the Barapukuria Basin imply a tectonically active highly disturbed zone (GSB, 1996).

\section{Data Collection and sample preparation}

To accomplish the task of assessment simple random sampling was used for the primary data collection. Then these data were edited and arranged in the form of qualitative data. To qualify and elucidate this impact, relevant data were collected from relevant papers and news papers. An investigation on the chemical properties of coal, coal water, soil and plant samples were also conducted to find out the properties of coal and coal water and their effect on soil and plant. Preparation of collected (water, coal and soil) sample for analysis goes through some process like air-drying, grinding and storing.

\section{Methods of sample analysis}

The methods and materials used to analyze the coal, coal water and soil are: $\mathrm{pH}$ by $\mathrm{pH}$ meter, Electrical Conductivity by ECmeter Total dissolved solids by TDS meter, Dissolved oxygen by DO meter and Biochemical oxygen demand by BOD meter. Available potassium, $\mathrm{Ca}, \mathrm{Mg}$, phosphorus, sulphur, $\mathrm{Zn}, \mathrm{Cu}, \mathrm{Fe}$ are measured by using flame photometer, by extraction method, Olsen's method, spectrophotometer and Atomic Absorption Spectrometer respectively.

\section{Organic carbon}

The soil organic carbon was calculated using the following formula:

$(\%)$ organic carbon $=\frac{V 1-(V 2 \times N)}{W} \times 0.003 \times 1.3 \times 100$ Where,

$\mathrm{V}_{\mathrm{i}}=$ Volume of $\mathrm{K}_{2} \mathrm{Cr}_{2} \mathrm{O}_{7}$ solution

$\mathrm{V}_{2}=$ Volume of $\mathrm{N} \mathrm{FeSO}_{4}$. solution

$\mathrm{W}=$ Weight of soil, $\mathrm{N}=$ Normality of $\mathrm{FeSO}_{4}$ solution and 1.3-Conventionalrecovery factors. 


\section{Results and Discussion}

\section{Concentration of $\mathbf{p H}$}

According to this study $\mathrm{pH}$ of sedimentation tank soil, coal water treated farm soil and normal farmers' field soil are showed (Fig.1), where the soils collected from sedimentation tank showed $\mathrm{pH}$ value higher than coal and coal water. The $\mathrm{pH}$ of soil further increased over coal, coal water and sedimentation tank soil and become the highest when the coal water was added to the normal farmland. This indicated that application of coal water increased the $\mathrm{pH}$ of soil by almost 1.22 times over the farmers' field soil. It is apparent from the results that between coal, coal water and soil of sedimentation tank, the $\mathrm{pH}$ of coal were the lowest and the $\mathrm{pH}$ of sedimentation tank soil was the highest.

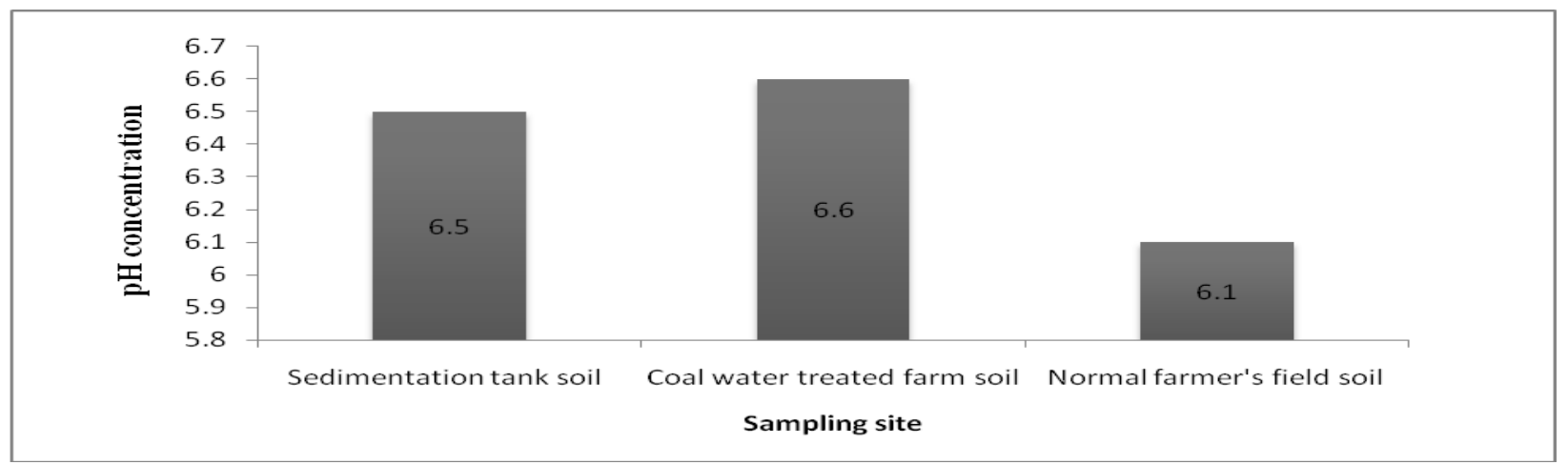

Figure 1. Concentration of $\mathrm{pH}$ in three different sources.

\section{Organic carbon}

Figure 2. Shows status of organic carbon content of coal was extremely high (51.07). The organic carbon content of sedimentation tank soil was $7.10 \%$ which indicated lower organic carbon than coal. The organic carbon content of sedimentation tank soil (7.1) and coal water treated farm soil (7.82) was nearly same but both indicated higher organic carbon whereas normal farmer's field soil nearby the coal water treated land it was found 1.55.This indicated that application of coal water increased the organic carbon of coal water treated farm land by almost 6.27 units over the organic carbon percentage of normal fanners' field soil lower organic carbon content of sedimentation tank soil than coal suggest that dilution of coal in water reduced its organic carbon content than coal.

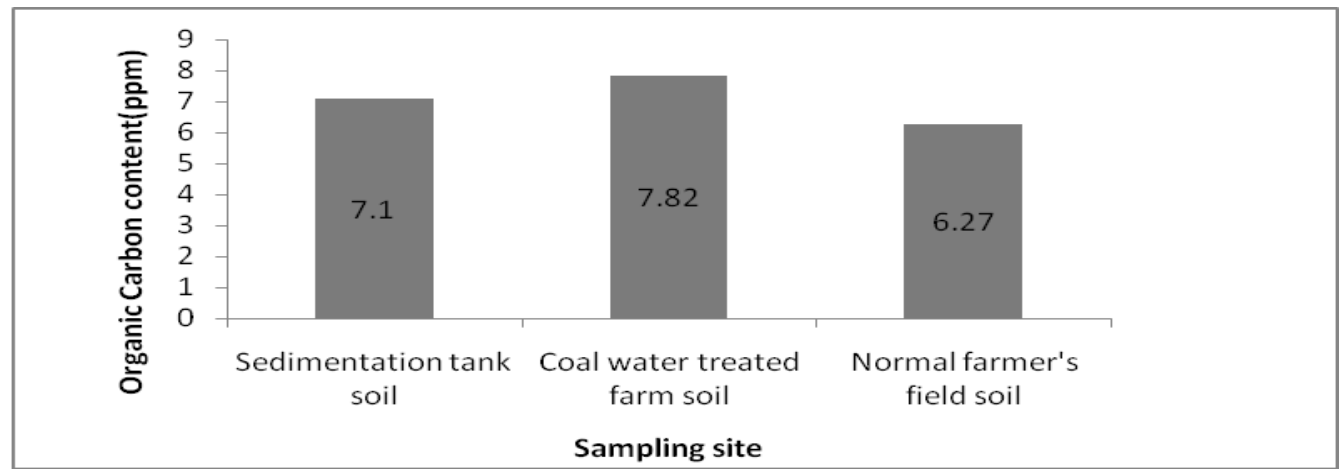

\section{Potassium}

Figure 3. Shows status in coal and coal water was $3.91 \mathrm{ppm}$ and $7.2 \mathrm{ppm}$ respectively. $\mathrm{K}$ content of sedimentation tank soil was $93.84 \mathrm{ppm}$ which was extremely high when compared with coal and coal water. The higher $\mathrm{K}$ content in coal water than coal suggest that $\mathrm{K}$ in coal water mainly dissolved from sediments i.e. inorganic $\mathrm{K}$ minerals through weathering by organic acids. This increase in $\mathrm{K}$ content in water treated soil was mainly due to application of high $\mathrm{K}$ containing coal water as well as initial soil content. Field observation indicated that only 3-4 cm standing water always remain in the coal water treated field. As a consequence of this standing water $\mathrm{K}$ was continuously added to the soil. 


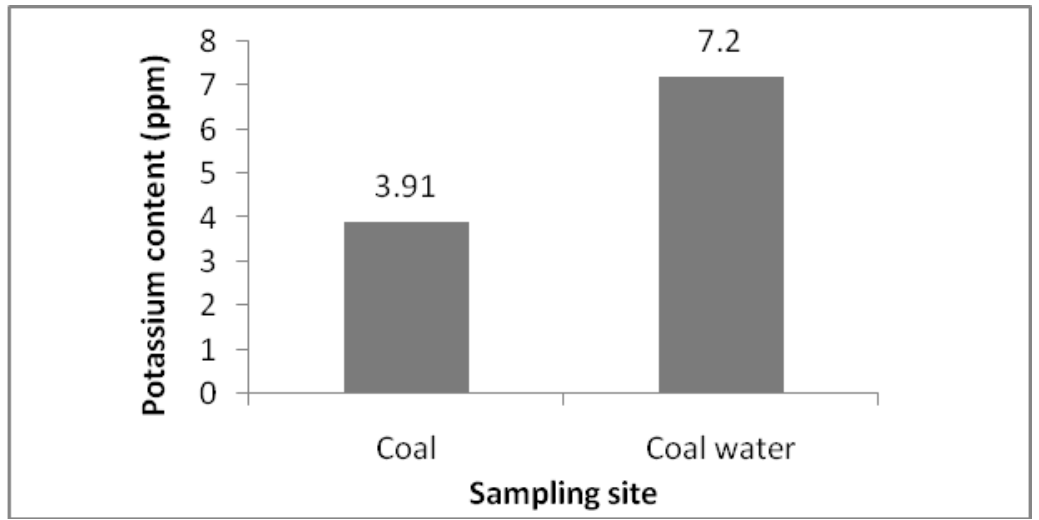

Figure 3. Potassium (K) status in coal and coal water.

\section{Phosphorus}

The available phosphorus content in sedimentation tank soil, coal water treated field soil and untreated farmers field soil was $9.08,11.10$ and $6.16 \mathrm{ppm}$

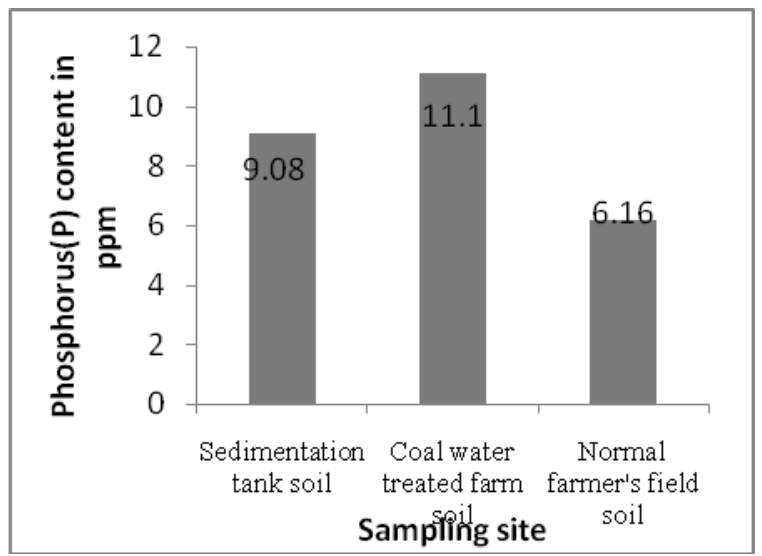

Figure 4. Status of Phosphorus content

This increase in $\mathrm{P}$ content in sediment was possibly due to gradual deposition of $\mathrm{P}$ from water as well as the sediment carried by water. Although P content of coal water was negligible (0.334 ppm) but in coal water treated farm soil it was higher than farmers' field soil $(6.16 \mathrm{ppm})$ due to continuous addition from applied coal water.

\section{Calcium}

The higher concentrations in coal water indicated adsorption of this basic cation from coal with high initial content in normal irrigation water. Again gradual sedimentation from this coal water in respectively (Fig. 4 and Fig. 5). The $\mathrm{P}$ content of coal was $3.51 \mathrm{ppm}$ whereas in coal water it was $0.334 \mathrm{ppm}$ and become higher in sedimentation tank soil.

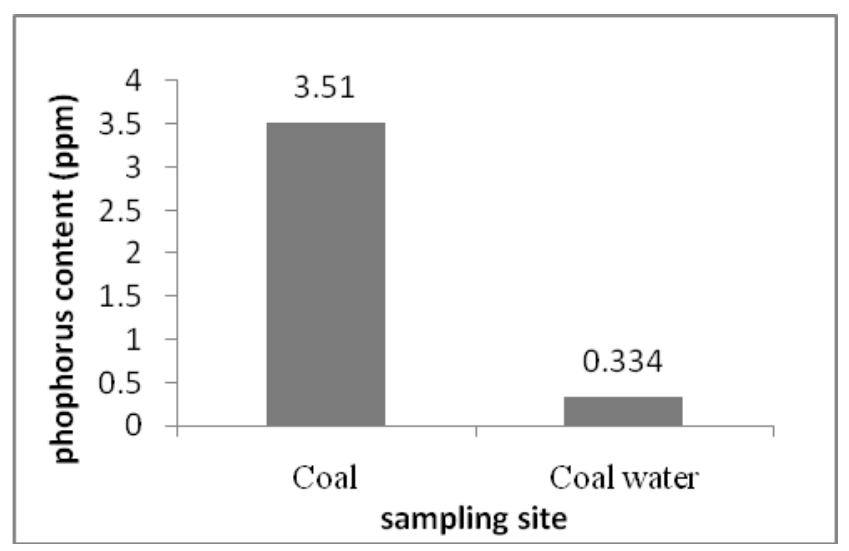

Figure 5. Phosphorus statuses in coal and coal water

sedimentation tank soil increased the Ca content up to $502.83 \mathrm{ppm}$ as well as initial soil content. This increase in $\mathrm{Ca}$ content in sediment was possibly due to gradual deposition of $\mathrm{Ca}$ from water as well as the sediment carried by water (Fig. 6 and Fig .7). In similar way $\mathrm{Ca}$ concentration in coal water treated farm soil was 1.10 times higher over the normal farmers' field soil possibly due to adsorption from coal water. The mine was discharging water approximately at rate of 400 to 600 cubic meters per hour (Imam, 2005) and farmers are using this discharged coal water continuously for irrigation purpose for a decade. 


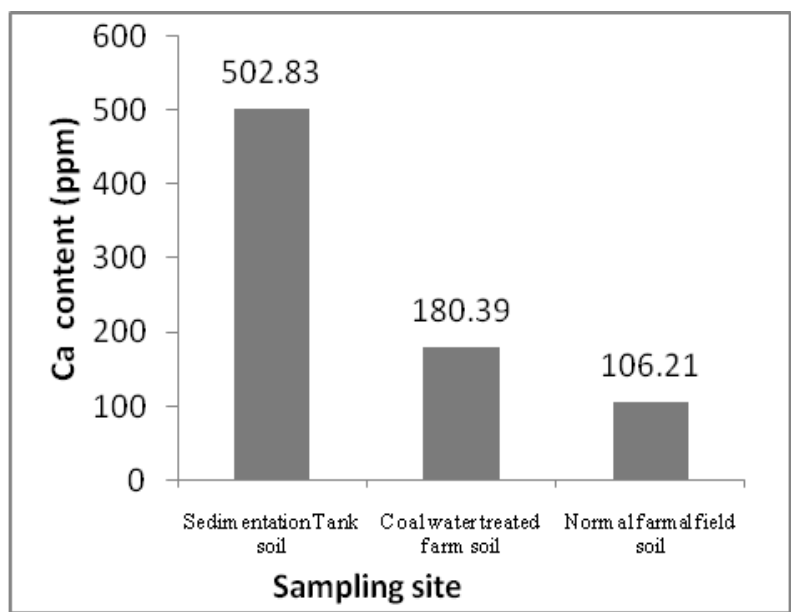

Figure 6. Status of Calcium

\section{Magnesium}

After discharging, provisional deposition of coal water in sedimentation tank increased the $\mathrm{Mg}$ content of the sedimentation tank soil up to $183.36 \mathrm{ppm}$. The $\mathrm{Mg}$ content of soil further increased over coal, coal water, sedimentation tank soil, normal farmers' field soil and

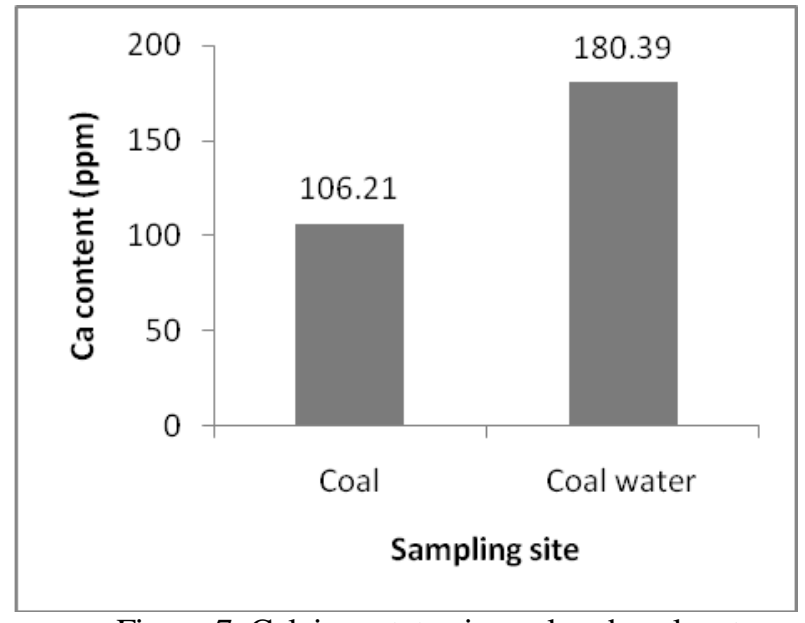

Figure 7. Calcium status in coal and coal water

become the highest when coal water was added to the normal farmland (Fig. 8). The Mg content of coal water treated farm soil nearby the normal farmers' field soil was found $200.73 \mathrm{ppm}$ which was almost 1.02 times higher than the $\mathrm{Mg}$ content of normal farmers' field soil (145.09 ppm) (Fig.9).

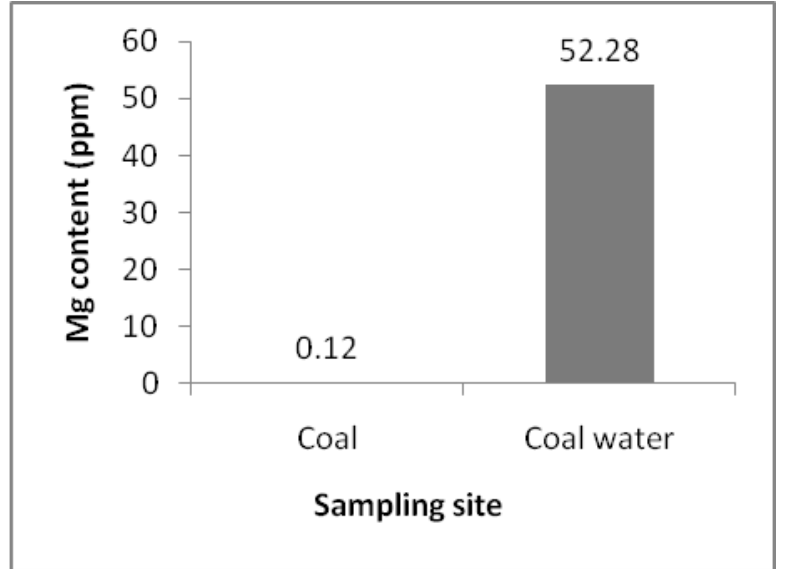

Figure 8. Magnesium status in coal and coal water.

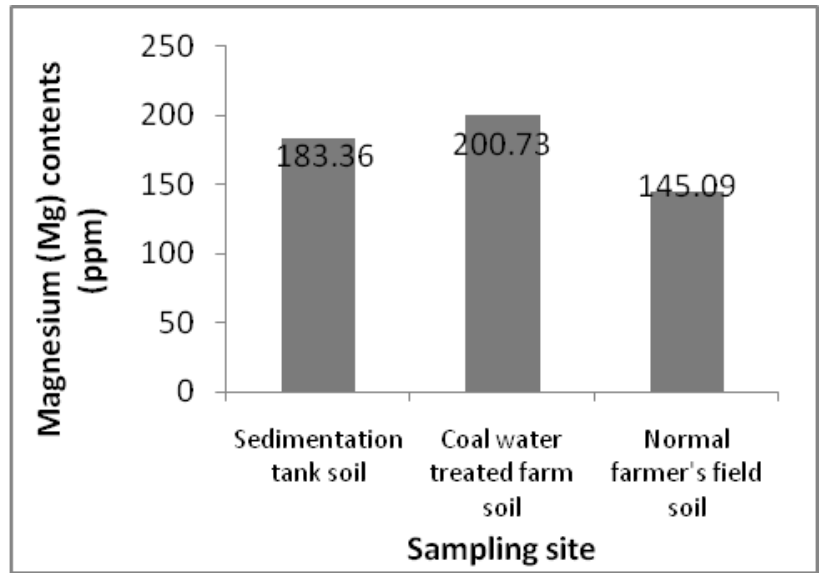

Figure 9. Status of Ma gnesium.

\section{Sulphur}

S content of coal was extremely high (4800 ppm) whereas in coal water the concentration was very low (0.19 ppm). Sorption of Sulphur from coal water at deeper depths was the main reason for the obtained high status in sedimentation tank soil. This was also further evident of high $\mathrm{S}$ content of coal water treated

farm soil (220.2 ppm) over the normal farmers' field soil of $30.78 \mathrm{ppm}$. The $\mathrm{S}$ content of coal water treated farm soil was 7.15 times higher than the normal farmers' field soil. Coal water was continuous added to the normal farmers' field soil for rice production (Figure 10). 


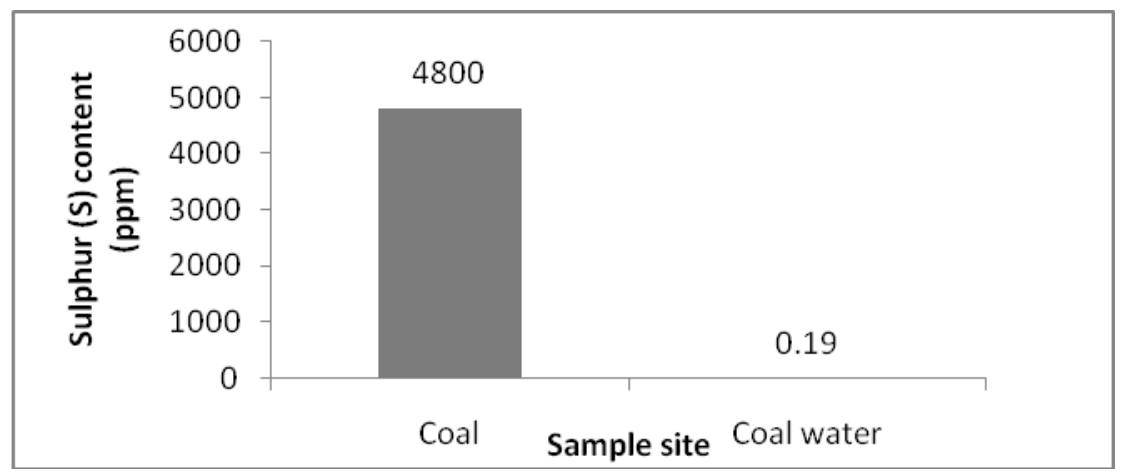

Figure 10. Sulphur (S) statuses in coal and coal water.

In the table (Table.1) the proposed Bangladesh and FAO standard for water has given. The $\mathrm{pH}$ values measured in Barapukuria coal mine industry all of the samples has a $\mathrm{pH}$ value of lower than 7 which is slightly acidic. Most of the aquatic organisms flourish best in neutral environment and any change in $p^{\prime \prime}$ affects then adversely. The standard value of $p^{\mathrm{H}}$ is 6 to 8.5. The $\mathrm{P}^{\mathrm{H}}$ of coal leached water is 6.66 where the $\mathrm{pH}$ of surrounding pond water is $6.7, \mathrm{pH}$ of ground water 6.9 and the $\mathrm{pH}$ of mine drainage water is 6.2(Figure 11). Here the $\mathrm{pH}$ of mine drainage water 1.08 times lowers than pond water which is affected. Again the ground water 1.04 times higher than coal leached water.

Table 1: Water quality standard for irrigation.

\begin{tabular}{|c|c|c|c|}
\hline Parameter & Units & $\begin{array}{c}\text { Proposed standard for } \\
\text { Bangladesh }\end{array}$ & FAO standard \\
\hline $\mathrm{pH}$ & -- & $6.5-8.5$ & $6.5-8.5$ \\
\hline $\mathrm{EC}$ & $\mu \mathrm{S} / \mathrm{cm}$ & 750 & -- \\
\hline TDS & $\mathrm{ppm}$ & 2000 & 450 \\
\hline Chloride & $\mathrm{ppm}$ & 600 & 142 \\
\hline Cadmium & $\mathrm{ppm}$ & 0.01 & -- \\
\hline
\end{tabular}

Source: Department of Environment (DoE), 2005.

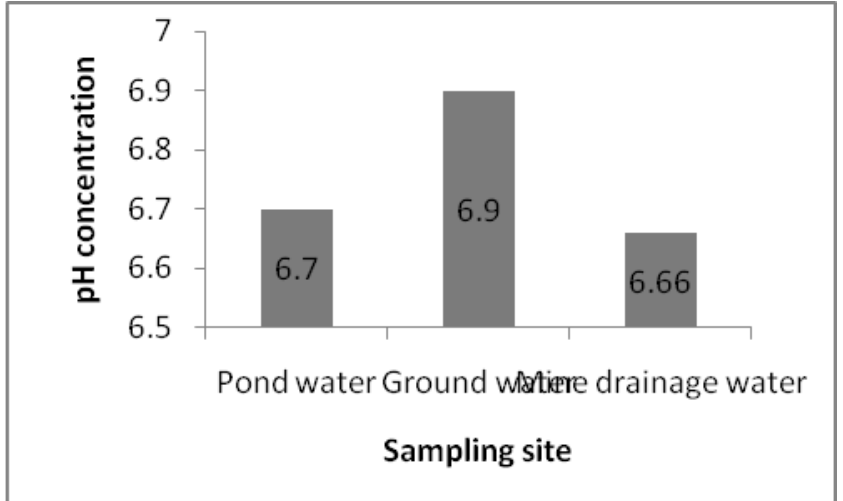

Figure 11. Level of $\mathrm{pH}$ in water.

From the Fig. 12. Shows that, the temperature in mine drainage water is $30.9{ }^{\circ} \mathrm{C}$, the temperature in pond water is $31.3{ }^{\circ} \mathrm{C}$ and temperature value in ground water is $29^{\circ} \mathrm{C}$. Here the temperature of pond water more than ground water and mine drainage water. The mine drainage water become warmer than ground water and the pond water warmer than ground water

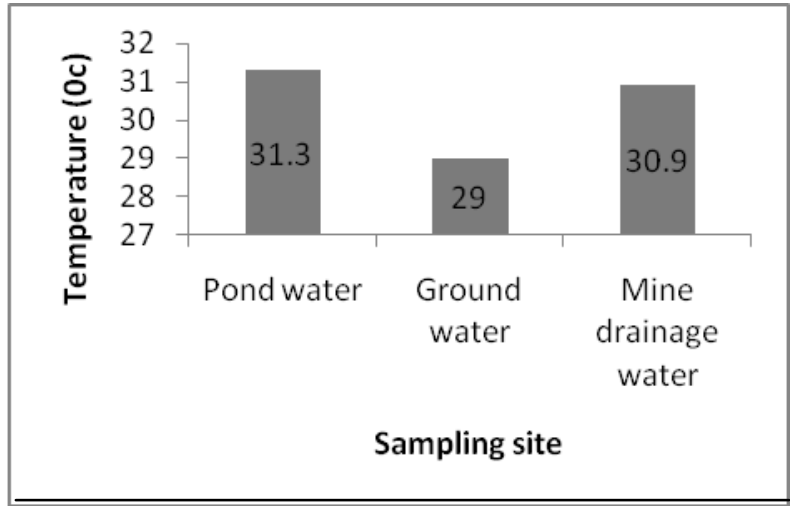

Figure 12. Temperature $\left({ }^{\circ} \mathrm{C}\right)$ variation in water.

and mine drainage water.The value of DO in pond water is $4.3 \mathrm{ppm}$, in ground water DO value is 5.8 and the DO value in mine drainage water is 2.44 . Here DO value of mine drainage water is 1.76 times and 2.37 times lower than pond water and ground water respectively (Fig. 13). 


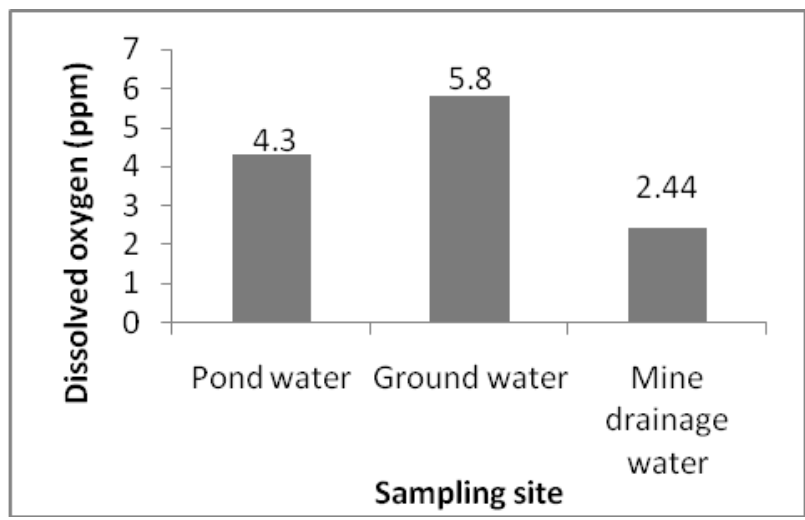

Figure 13. Level of DO in water.

\section{Level of BOD}

From the fig.14 shows that, pond water had 1.1, ground water 5.0 and mini drainage water 2.14 respectively.

\section{Conclusion}

Bangladesh is an energy-starved country where 90 percent of its commercial electricity generates from natural gas reserves, but depletion is a big concern as they are expected to run out between 2015 and 2020. Security of supply in the energy sector is argued to be one of the most significant barriers to development. Already coal mining is started there and it becomes a great problems for the people especially for the farmer's of this regionand it also creates a great threat to the naturalenvironment. Coal is expected to aid in providing energy security for the country in short term. But it impacts our natural environment greatly. It contaminates water and soil greatly. The water quality surrounding the mining industry are greatly polluted as a consequences of mining. The chemical properties of surrounding water such as concentration of Calcium, Magnesium, Lead, Iron, Copper, Zinc etc are greatly increased by the mixing of coal water and greatly impacts on the farmer's field soil. These impacted water quality may also hamper on flora and fauna of the surrounding environment of the Barapukuria Coal mining.

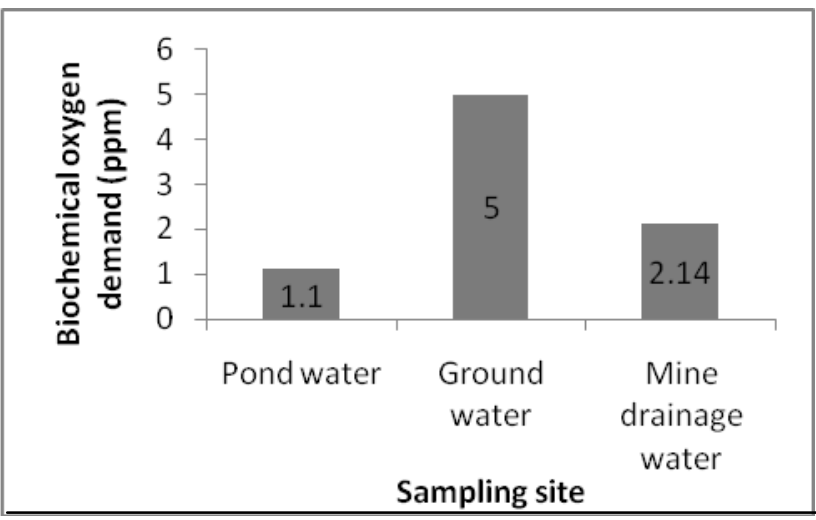

Figure 14. Level of BOD in water.

\section{References}

Armstrong, W. 1991. Techno-economicFeasibility Study: Barapukuria Coal Project, Dinajpur, Bangladesh.

Banglapedia. 2006. National Encyclopedia of Bangladesh. Asiatic Society of Bangladesh.

GSB Report 1996. Geology and Coal deposit of Barapukuria Basin, Dinajpur District, Bangladesh.

Imam, B. 2005. Energy Resources of Bangladesh. University Grants Commission of Bangladesh, Agargaon, Dhaka, Bangladesh, pp. 179-191.

Jaccard, M. 2005. Sustainable fossil fuels: The unusual suspect in the quest for clean and Enduring energy. United States of America: Cambridge University Press.

Martha. K., 2001. Clean Air Task Force, Cradleto Grave: The Environmental Impacts from Coal.

Hamilton, M. 2005. Mining Environmental Policy: Comparing Indonesia and the USA Hampshire: Ashgate Publishing Limited. 